\title{
Study of blood and pubic hair mineralograms of alcoholic people
}

\author{
Heliane Sousa DA SILVA ${ }^{1}$, Sandra Terezinha de FARIAS FURTADO ${ }^{1 *}$, \\ Dáurea Abadia DE SOUZA ${ }^{2}$, Luis Carlos Marques DE OLIVEIRA ${ }^{2}$, \\ Carlos Alberto DE OLIVEIRA ${ }^{1}$ and Graziele BENEDETTI ${ }^{2}$ \\ ${ }^{1}$ Universidade Federal de Uberlândia, Instituto de Química; Av. João Naves de Ávila, $n^{\circ} 2121$, \\ CEP - 38400-042, Uberlândia, MG - Brasil; Tel: +55 343239 4143; +55 3491720218. \\ ${ }^{2}$ Faculdade de Medicina, Universidade Federal de Uberlândia, Brasil. \\ ${ }^{*}$ Corresponding author; E-mail: sandrafariasf@gmail.com
}

\begin{abstract}
The quantification of minerals present in the blood and pubic hair of alcoholic people is of paramount importance, since the excessive consumption of liquor over several years can cause an imbalance of minerals. In this sense, the present study sought to compare the mineralograms of pubic hair and blood of alcoholic and non-alcoholic persons. After making the opening of the samples, the concentrations of minerals were obtained by Atomic Emission Spectroscopy with Inductively Coupled Plasma (ICP-MS). Statistical analysis was performed in 5.0 BioEstat. Statistical differences were considered at $\mathrm{p} \leq 0.05$. The results show that there was a significant increase in concentrations of iron, manganese and copper in the pubic hair of alcoholics compared to the control group. The average concentration in $\mathrm{mg} \mathrm{L}^{-1} \mathrm{Fe}, \mathrm{Mn}$ and $\mathrm{Cu}$ found in the pubic hair of group A were respectively: $83.8(\mathrm{p}=0.029) ; 2.894(\mathrm{p}=0.021)$ and $9.6(\mathrm{p}=0.0144)$. These data show that ingestion of liquor contaminated with copper and the metabolism of alcohol itself are compromising the balance of minerals in the body of those patients and may lead to premature aging.

(C) 2013 International Formulae Group. All rights reserved.
\end{abstract}

Keywords: Rum, alcohol, hair analysis, biological materials.

\section{INTRODUCTION}

The human organism depends on several reactions resulting from the proper functioning of our cells. Some of the elementary constituents of blood composition, such as the elements $\mathrm{Cu}, \mathrm{Zn}, \mathrm{Fe}, \mathrm{P}, \mathrm{Ca}, \mathrm{Mg}$, $\mathrm{Mn}, \mathrm{K}$ are essential to life. It may be mentioned as an example, calcium and magnesium, which work in the formation of bones, teeth and tissues (Alonso et al., 2004).

Studies on bioavailability allowed to know that the metabolism of minerals can not be considered in isolation. Physiological and nutritional factors may interfere with the absorption, transport and storage, with subsequent increased susceptibility to deficiency or toxicity (Alonso et al., 2004).

One of the factors that affect the bioavailability of minerals concerns the interactions that occur between them (Fraga, 2005). According to Block et al. (2004), interactions between minerals can occur either directly or indirectly. The direct interactions are generally competitive phenomena that occur during the intestinal absorption and tissue utilization, while the indirect occur 
when a mineral is involved in the metabolism of another, so that a deficiency of one can cause a loss of function of the other. Thus, for the proper functioning of the organism, the concentrations of minerals should be within the proper range, since they are cofactors of several enzymes that act in metabolism.

Alcoholic beverages have been used by man for various purposes such as anxiety reduction, promoting greater social contact, and represent a form of political domination, as the active ingredient of alcoholic beverages; the ethanol initially produces a state of euphoria and disinhibition, followed by a depressive effect on the nervous system (Regina, 2004).

Ethanol is an organic compound obtained by the fermentation of starches, which contain sugars such as sucrose present in sugar cane. Alcohol is a psychoactive substance which is present in alcoholic beverages, and therefore, their inappropriate use can have serious consequences both rganic, psychological and social, characterizing the condition known as alcoholism, now treated as the dependence syndrome Alcohol (Philippi, 2003).

Cachaça is a typical and exclusive designation of brandy sugar cane produced in Brazil (Brazil, 2003) and, during its manufacturing process, it is distilled and stored around copper. In this process, they form an insoluble compound of copper, on which it is dissolved in acid vapors during cachaça distillation, thus contaminating the product (Miranda et al., 2010).

His, the individual who ingests liquor throughout his life, can have accumulation of copper in his body. Copper is beneficial in appropriate concentrations, it participates in numerous metabolic reactions (Gaetke and Chow, 2003). However in excess, can be harmful to human health, since this mineral is associated with neurodegenerative diseases (Mancía et al., 2010).

In this regard, this article aims at studying and comparing the mineralograms of alcoholic and non-alcoholic people from the quantification of minerals in biological materials like blood and pubic hair.

\section{MATERIALS AND METHODS}

Approval of work and recruitment of research subjects

For the development of this work with human beings, the same was submitted and approved by the Ethics Committee in Human Research at the Federal University of Uberlândia-Brazil (CEP/UFU), receiving the registry ZIP/UFU no. $241 / 10$ and appear of approved no. 410/10, on July 02, 2010.

We evaluated 30 subjects, all males above 18 years of age and divided into two groups: group A was composed of 15 subjects not suffering from hepatic cirrhosis and group $\mathrm{C}$ (control group) comprised 15 non-alcoholic subjects.

Recruitment of Group A was made in CAPS - Center for Social Support Psychic Federal University of Uberlândia and recruitment of Group $\mathrm{C}$ was made in the Department of Orthopedics, Hospital of the UFU. During the approach, we applied the term of consent and also passed all the explanations about the research subject: copper poisoning caused by ingestion of cachaça, about research in general and about the risks and benefits provided by this work. Two questionnaires were applied: the first was on the frequency in which the subjects ingest cachaça and about their individual data: age, time and quantity of alcohol consumed and the second questionnaire entitled "Test whether you are feeding", then later the biological material was collected from patients.

\section{Collection and opening of the biological sample \\ Blood}

Were collected from each patient $10 \mathrm{ml}$ of venous blood in special tubes containing no silicon, heparin, and analyzed at the Institute of Chemistry, Federal University of Uberlândia. The digestion of samples was made in flasks for digestion.

Two ounces of blood were weighed on an analytical balance; this mass was added 
$0.25 \mathrm{~mL}$ of $30 \% \mathrm{H}_{2} \mathrm{O}_{2}, 1.0 \mathrm{~mL}$ of $\mathrm{H}_{2} \mathrm{O}$ and 4.0 $\mathrm{mL}$ of $65 \% \mathrm{HNO}_{3}$ using powers suggested in the equipment itself. The vials were sealed and taken to the microwave DGT. At the end of digestion, the samples were cooled and supplemented with deionized water until the volume of $10 \mathrm{~mL}$.

\section{Pubic hair}

From each patient were collected 0.5 gram of pubic hair that was stored in plastic bags. Hair samples were analyzed in all its entirety, in the Biominerals Company. The digestion of samples of pubic hair were made in vials for digestion and 0.35 gram of hair were weighed on an analytical balance. To this mass, were added $3.0 \mathrm{~mL}$ of $65 \% \mathrm{HNO}_{3}$ and $0.25 \mathrm{~mL}$ of $30 \% \quad \mathrm{H}_{2} \mathrm{O}_{2}$ in powers suggested by the equipment itself. The vials were then sealed and taken to the microwave. At the end of digestion, the samples were cooled and supplemented with deionized water to $10 \mathrm{~mL}$.

\section{Reading of the samples}

For the determination of phosphorus, the readings were taken at a wavelength of $660 \mathrm{~nm}$ in a spectrophotometer UV-Vis $600 \mathrm{~S}$ Femton using the molybdenum blue method (ESTELA and CERDÁ, 2005) and for the determination of other metals, the absorbances were read on atomic absorption unit with a specific lamp for each metal. The Biominerals Company made the determination of metals using the following equipments: Plasma Emission Spectrometer (ICP) and Graphite Furnace coupled to Atomic Absorption Spectrophotometer (GFAAS).

\section{Statistical analysis}

Statistical analysis was performed using the program BioStat 5.0. Due to nonnormal distribution of probability, the MannWhitney test was used for the statistical differences between groups. A p $<0.05$ was considered statistically significant.

\section{RESULTS}

The individual data of each subject showed that the average age of patients in group A was 46 years, each subject began to make use of liquor at about 14 years of age ingesting approximately 1.34 liters of beer every day and, the average age of Group B was 47 years. The concentrations of minerals $\mathrm{Zn}, \mathrm{Cu}, \mathrm{Mg}$ and Fe were obtained by atomic absorption spectroscopy and phosphorus by spectrophotometric analysis of the molybdenum blue. The calibration curve for the analysis of phosphorus spectrometry method using molybdenum blue is found in Figure 1 and the calibration curves for $\mathrm{Zn}, \mathrm{Cu}$, $\mathrm{Fe}$ and $\mathrm{Mg}$ obtained by atomic absorption spectroscopy in Figures 2, 3, 4 and 5 respectively.

The average of the concentrations of minerals that were quantified in biological materials mentioned above, are in Tables 1 and 2. By analyzing the results, it can be observed both in the mineralograms of pubic hair and of blood that the alcoholic patients showed a significant increase in the concentrations of copper, iron, manganese and sodium compared to the control group.

The average concentrations in mg. $\mathrm{L}^{-1}$ of the above metals present in the pubic hair of group A are respectively: 9,6 ( $\mathrm{p}=0,0144)$, $83.8(\mathrm{p}=0,029), 2,894(\mathrm{p}=0,021)$ and $1041,13$ ( $p=0,0401)$. The concentration of zinc in the group of alcoholic patients is reduced when compared to the control group, as shown in Tables 1 and 2. For the minority of the individuals alcoholic, zinc concentration was within the appropriate values probably because they were in a more balanced diet, as shown in Table 4.

This decrease of zinc in alcoholic patients when compared to the control group probably occurred by ingestion of alcoholic beverage, in which the metabolization of ethanol compromised the absorption of various minerals and vitamins (Ross et al., 2012). Zinc deficiency can affect cognitive development, changing attention, neurophysiological behavior and motor activity. This ion is essential for neuronal physiology: acts as a modulator of synaptic response, emphasizing that its action profoundly affects excitatory synapses, which 
obviously generates changes in neural transmission (Sena, 2005).

Table 3 shows the minimum and maximum concentration of minerals present in the human pubic hair found in the laboratory of the Biominerals Company.

Figure 6 shows the average concentration of iron in the body of research subjects. The iron concentration range considered normal in the hair is 10 to 47 mg. $\mathrm{L}^{-1}$. It can be seen that the control group presents the average value of 31.2 which is within this range, while the group of subjects cachaça consumers, the average concentration of iron has a value of 83.8, a fairly large number compared with group $\mathrm{C}$. This is because often, the cachaça contain high levels of iron, this fact justifies the rare presence of anemia due to iron deficiency in alcoholics (Ross et al., 2012).

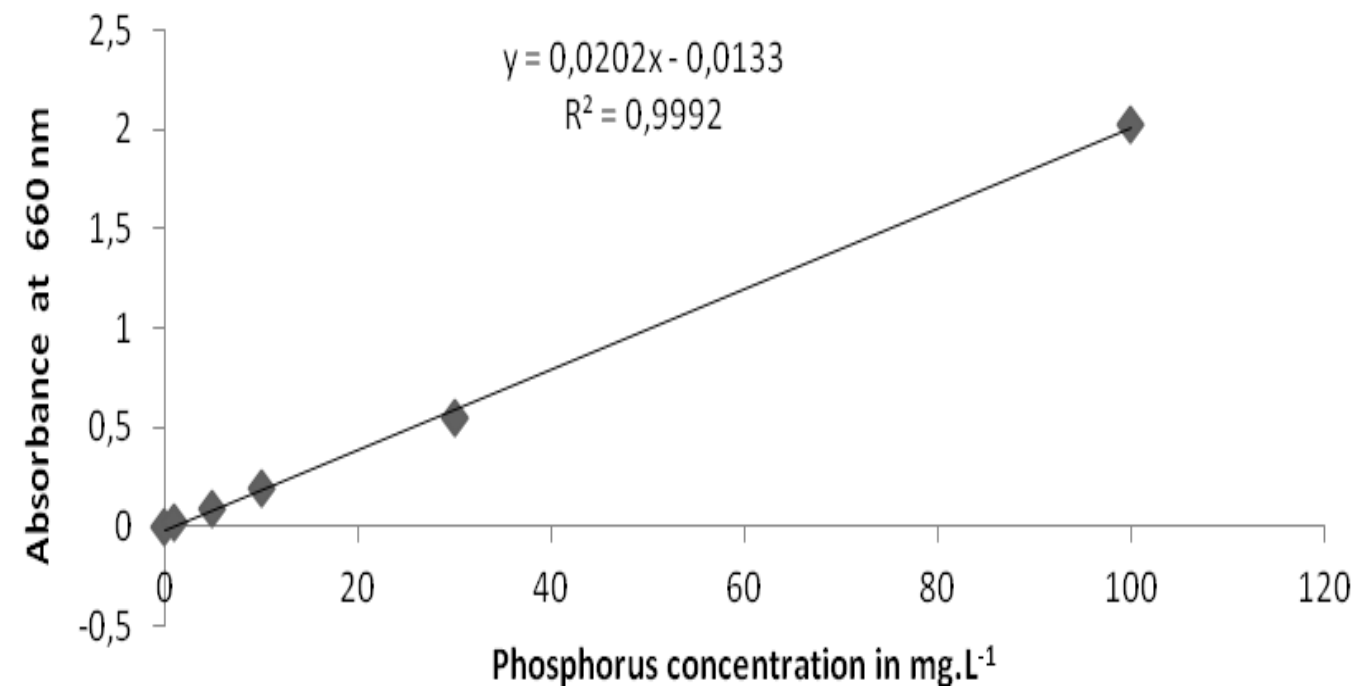

Figure 1: Calibration curve of the phosphorus obtained in the UV-Vis spectrophotometer.

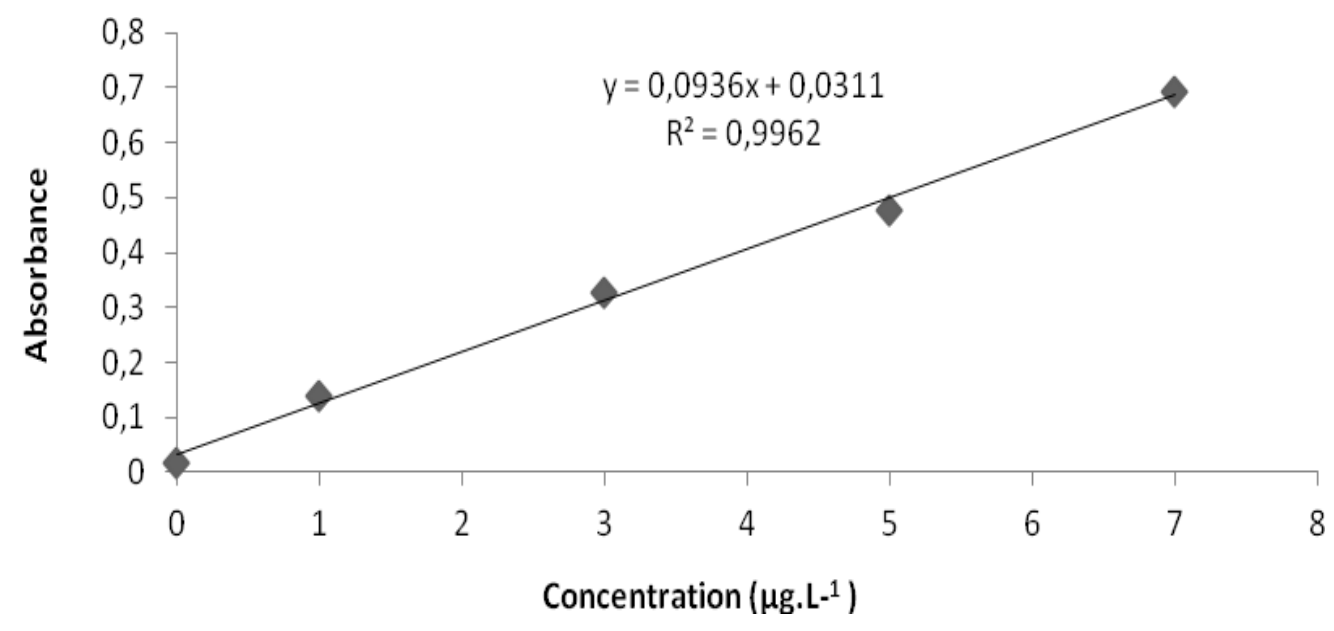

Figure 2: Calibration curve of zinc. 


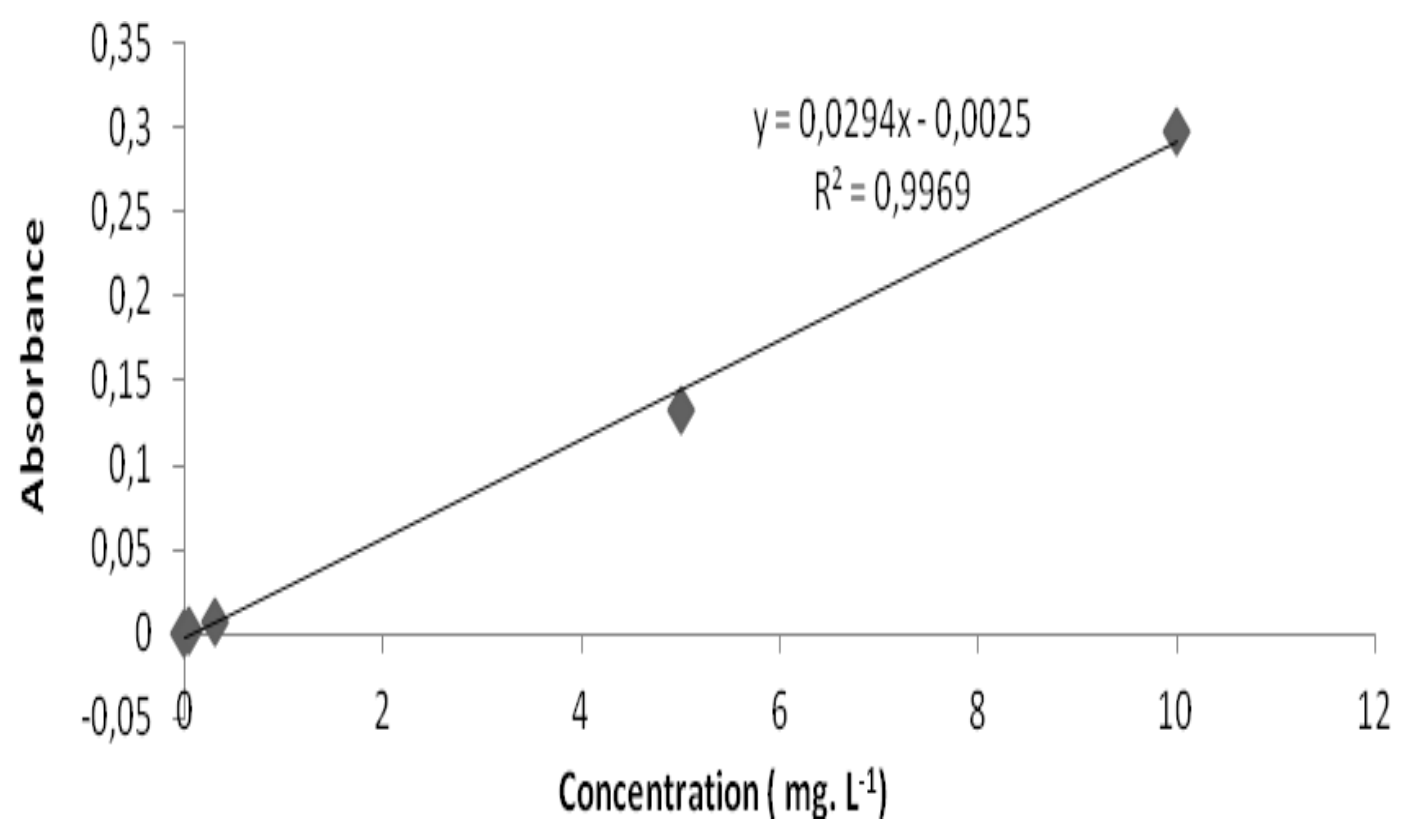

Figure 3: Calibration curve of copper.

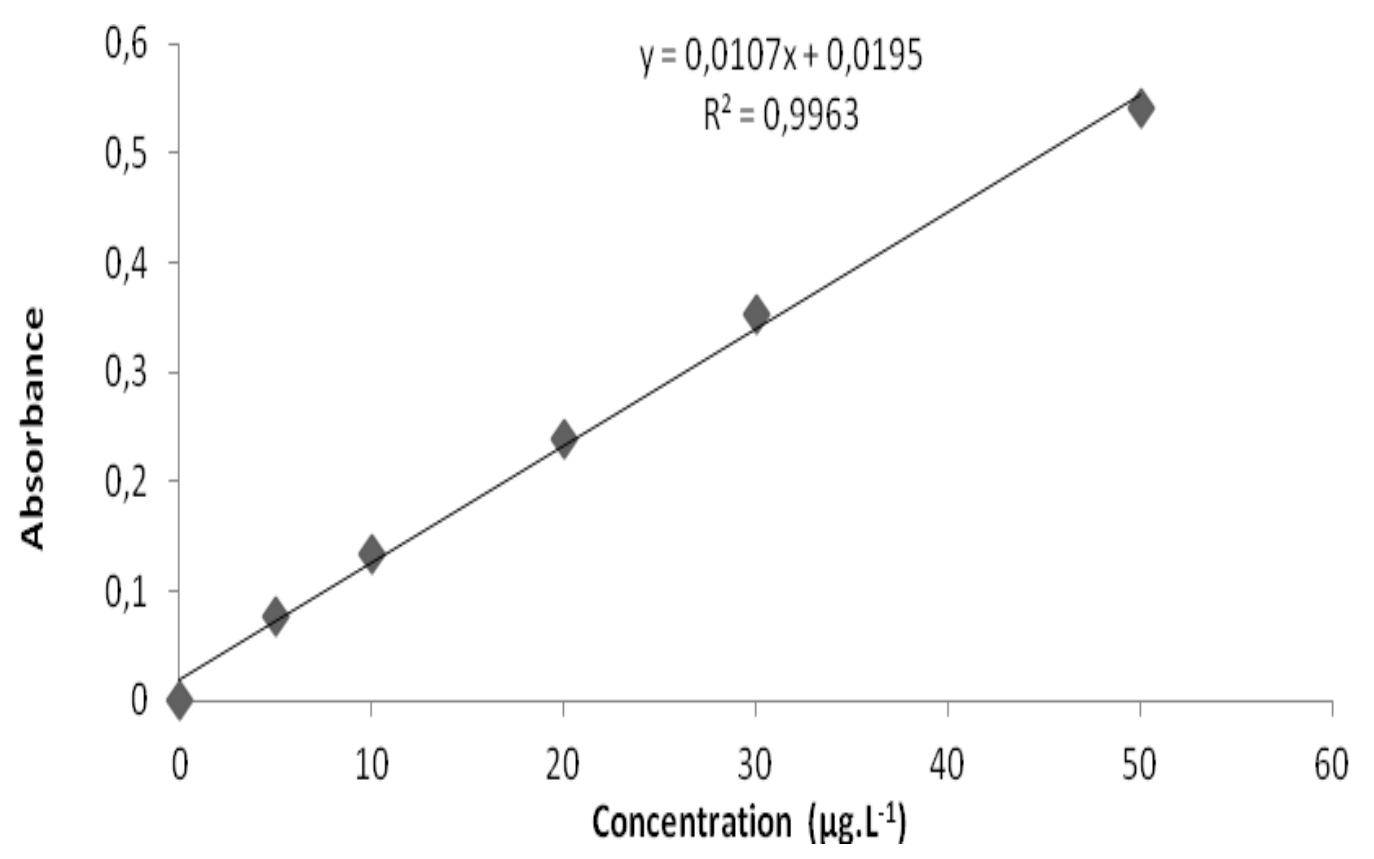

Figure 4: Calibration curve of iron. 


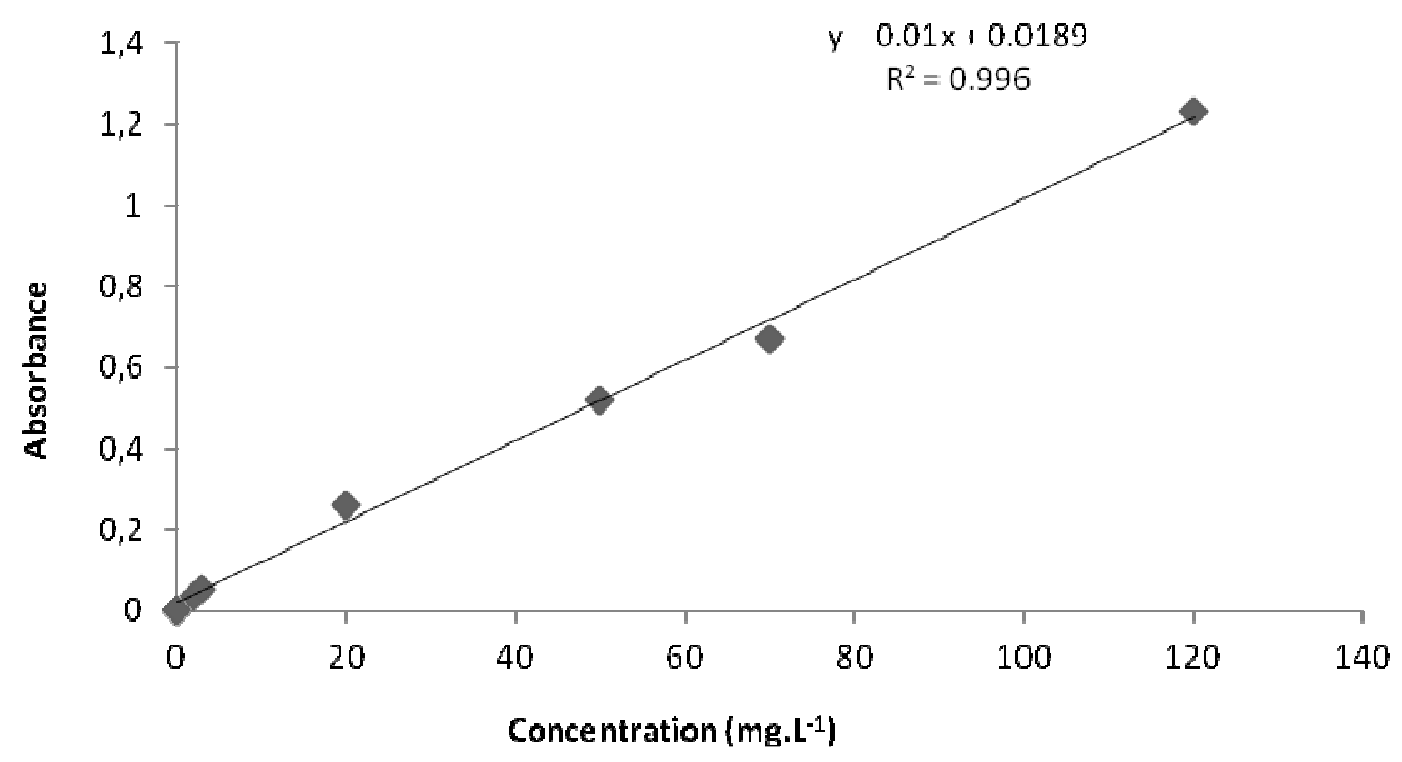

Figure 5: Calibration curve of magnesium.

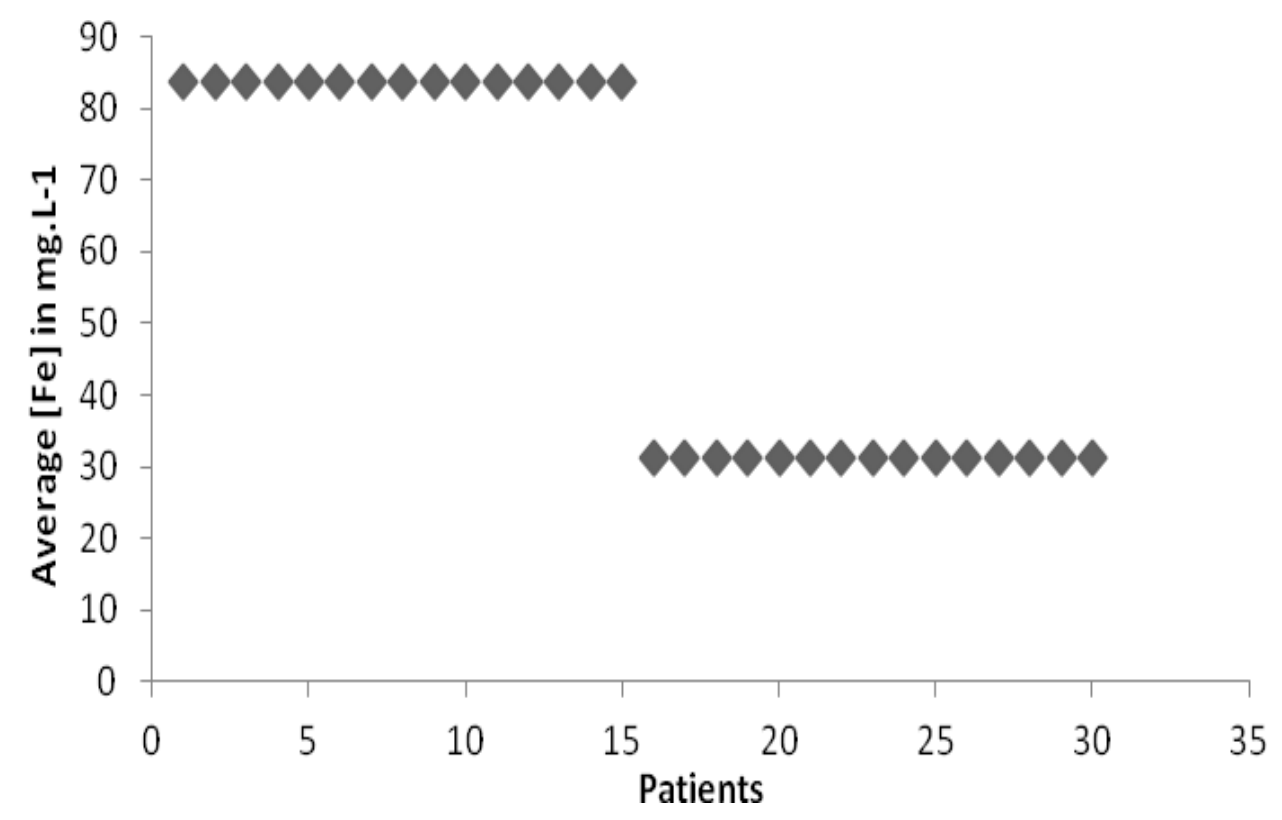

Figure 6: Average iron concentration in human hair. Samples 1 to 15 represent the group of alcoholics and samples 16 to 30 represent the control group. 
Table 1: Average concentrations of minerals in the pubic hair of patients.

\begin{tabular}{cccccc}
\hline Minerals & Group A $^{\mathbf{1}}$ & Group C $^{\mathbf{1}}$ & Group A $^{\mathbf{2}}$ & Group C $^{\mathbf{2}}$ & $\mathbf{p}$ \\
\hline$[\mathrm{P}]$ & 211 & 175.8 & 200 & 175 & 0.119 \\
{$[\mathrm{Mn}]$} & 2.894 & 1.066 & 2.07 & 0.67 & 0.021 \\
{$[\mathrm{Fe}]$} & 83.8 & 31.2 & 37 & 20 & 0.029 \\
{$[\mathrm{Zn}]$} & 122.33 & 129.8 & 123 & 124 & 0.6482 \\
{$[\mathrm{~K}]$} & 342.27 & 199.13 & 245 & 178 & 0.1524 \\
{$[\mathrm{Cu}]$} & 9.6 & 4.47 & 8 & 4 & 0.144 \\
{$[\mathrm{Mg}]$} & 81 & 33.73 & 48 & 18 & 0.0779 \\
{$[\mathrm{Na}]$} & 1041.13 & 399.67 & 629 & 326 & 0.0401 \\
{$[\mathrm{~V}]$} & 0.28 & 0.09 & 0.19 & 0.06 & 0.04 \\
{$[\mathrm{Cr}]$} & 0.36 & 0.19 & 0.24 & 0.13 & 0.0421 \\
{$[\mathrm{Se}]$} & 0.34 & 0.32 & 0.3 & 0.28 & 1.0 \\
{$[\mathrm{~S}]$} & 33288.13 & 36543.87 & 31242 & 35287 & 0.0649 \\
{$[\mathrm{Ca}]$} & 922 & 560.6 & 552 & 335 & 0.1013 \\
\hline
\end{tabular}

${ }^{1}$ Average $\left(\mathrm{mg} . \mathrm{L}^{-1}\right) ;{ }^{2}$ Median $\left(\mathrm{mg} \cdot \mathrm{L}^{-1}\right)$

Table 2: Average concentrations of the minerals quantified in patients' blood $\left(\mathrm{mg}^{-1} \mathrm{~L}^{-1}\right)$.

\begin{tabular}{cccccc}
\hline Minerals & Group A $^{\mathbf{1}}$ & Group C $^{\mathbf{1}}$ & Group A $^{\mathbf{2}}$ & Group C $^{\mathbf{2}}$ & p \\
\hline$[\mathrm{Zn}]^{*}$ & 1550.58 & 1554.69 & 1513.1 & 1586.3 & 0.5755 \\
{$[\mathrm{Cu}]^{*}$} & 301.12 & 273.32 & 288.1 & 267.4 & 0.088 \\
{$[\mathrm{Mg}]$} & 16.09 & 9.96 & 10.8 & 10 & 0.039 \\
{$[\mathrm{Fe}]$} & 175 & 174.10 & 170.8 & 186 & 0.9179 \\
{$[\mathrm{P}]$} & 128 & 122 & 159 & 142 & 0.5723 \\
\hline
\end{tabular}

${ }^{1}$ Average $\left(\mathrm{mg} . \mathrm{L}^{-1}\right) ;{ }^{2}$ Median $\left(\mathrm{mg} . \mathrm{L}^{-1}\right) ; *$ concentrations are in $\mu \mathrm{g} . \mathrm{L}^{-1}$

Table 3: Minimum and maximum concentrations in $\mathrm{mg} \cdot \mathrm{L}^{-1}$ of the different minerals present in the hair according to the company biominerals.

\begin{tabular}{|c|c|c|c|c|c|c|c|c|c|c|c|c|c|c|}
\hline & {$[\mathbf{P}]$} & {$[\mathrm{Ca}]$} & {$[\mathrm{Mg}]$} & [Na] & {$[\mathrm{K}]$} & {$[\mathrm{Fe}]$} & [Mn] & {$[\mathbf{c u}]$} & {$[\mathrm{Cr}]$} & {$[\mathbf{S}]$} & [se] & [V] & [Sr] & [Zn] \\
\hline $\begin{array}{l}\text { Maximum } \\
\text { value }\end{array}$ & 120 & 280 & 34 & 28 & 5 & 10 & 0.24 & 8 & 0.3 & 21200 & 0.18 & 0.1 & 0.5 & 125 \\
\hline $\begin{array}{l}\text { Minimum } \\
\text { value }\end{array}$ & 209 & 2500 & 200 & 400 & 165 & 47 & 1.0 & 45 & 1.4 & 45000 & 2.5 & 0.4 & 11 & 240 \\
\hline
\end{tabular}

Table 4: Profile of research subjects.

\begin{tabular}{lcc}
\hline & Control group & Alcoholic group \\
\hline Terrible food & $6.67 \%$ & $46.67 \%$ \\
Food near the desirable & $73.33 \%$ & $53.33 \%$ \\
Balanced diet & $20.00 \%$ & $0.00 \%$ \\
Often showed anger and irritability & $20.00 \%$ & $66.67 \%$ \\
Had some kind of sadness and depression & $0.00 \%$ & $60 \%$ \\
Loss of hair & $13.33 \%$ & $46.66 \%$ \\
\hline
\end{tabular}




\section{DISCUSSION}

Patients with accumulation of iron in the body may develop a disorder called hemochromatosis, where the excess iron will accumulate in the liver, pancreas and heart, and can lead to cirrhosis, liver tumors, diabetes mellitus and heart failure, because the serum transferrin in these patients may be almost completely saturated with iron (Madsen, 2007).

Daniel (2004) noted that an imbalance between zinc and copper, with high levels of copper and low zinc has been observed in lung cancer, there is a need, however, for elucidation of the role of trace elements in pre-cancerous states.

High concentrations of copper, manganese and iron in the human body are associated with neurodegenerative diseases like Parkinson's, Alzheimer's disease and multiple sclerosis (Brewer, 2010). These transition metals such as $\mathrm{Mn}, \mathrm{Cu}$ and $\mathrm{Fe}$, can donate or accept free electrons during intracellular reactions, catalyzing the formation of free radicals, such as the Fenton reaction: $\mathrm{H}_{2} \mathrm{O}_{2}+\mathrm{Fe}^{2+} \rightarrow \mathrm{Fe}^{3+}+\mathrm{OH}+\mathrm{OH}^{-}$ (Kumar, 2006). The free radicals formed, in turn, are extremely toxic, because they damages lipids, proteins, DNA and cellular RNA, leading to various forms of cellular injuries (Marks, 2006). Studies suggest that copper not only affects the formation of senile plaques, but also it is related in the formation of neurofibrillary tangles. It also showed that the protein beta amyloid in the pathogenesis of disease Alzheimer has high affinity for copper. The binding of the metal with this protein, possibly promotes amyloid beta toxicity through the formation of hydrogen peroxide and the subsequent generation of free radicals through the Fenton reaction, as has been widely reported for $\mathrm{Fe}$, this effect may involve an electron $\mathrm{Cu}$ (II) reduction by the action of amyloid beta (Brewer, 2012).
Hyperkalemia (excess potassium) from the clinical point of view can manifest from the absence of symptoms to cardiac arrest. Excitable cells are more sensitive to high concentrations of potassium, including myocardial cells and neuromuscular disorders, which results in weakness, muscle paralysis (even breathing). One factor that may be contributing to the increased concentration of potassium in pubic hair (Table 1) of the group of alcoholics in comparison with the control group, metabolic acidosis is caused by the metabolization of alcohol. Acidosis causes the output of potassium from the intra to the extracellular medium, increasing its serum concentration. This is because, when $\mathrm{H}^{+}$ions in excess are added to the plasma, most of it is buffered in the intracellular compartment, and so these ions enter the cells, they are exchanged for $\mathrm{Na}^{+}$pathway the $\mathrm{Na}^{+}-\mathrm{H}^{+}$, which decreases the concentration of intracellular $\mathrm{Na}^{+}$, and hence their willingness to be replaced by $\mathrm{K}^{+}$through the sodium and potassium. Thus, the lower amount of $\mathrm{K}^{+}$ enters cells (Vieira and Neto, 2003).

The analysis of the questionnaires on the individual data of each research subject and "how's my food," proposed by the Ministry of Health, showed that the imbalance probably caused by the ingestion of cachaça, with a consequent increase in the body of copper, other minerals such as $\mathrm{Zn}, \mathrm{Mg}, \mathrm{Na}, \mathrm{K}$, $\mathrm{Mn}$ and $\mathrm{Fe}$ is unbalanced and, given that their food is not adequate, they can not replenish and restore the balance of its minerals. As a result, they can not sleep well, have white spots on nails, hair white or yellowish and thin, are sad people, they feel very weak, tired breath, get easily angry, feel a lot of anger, feel depressed (Table 4). Hence, they can not restore their emotional balance, making it difficult to cure the addiction. 


\section{Conclusion}

Considering these results, we find that there is a symbiosis cachaça ingestion symptoms of deficiency and excess of minerals such as $\mathrm{Zn}, \mathrm{Mg}, \mathrm{Fe}, \mathrm{Mn}$ and $\mathrm{Cu}$. Therefore, it is believed that perhaps one reason why research subjects get back to drinking is because of their weak emotional state, caused in part by an imbalance of minerals led by the ingestion of the drink itself. Also, the accumulation of metals in the body such as copper, manganese and iron, can induce premature aging, since these minerals are involved in the formation of reactive oxygen species, which can injure and damage cell membranes, DNA, RNA and proteins. It is inferred that, if these research subjects are treated in order to balance their minerals, they will have a greater chance to recover from addiction.

\section{ACKNOWLEDGMENTS}

A special thanks to the Coordination of Improvement of Higher Education Personnel (CAPES) for providing the scholarship, and to the Clinics Hospital, of the Federal University of Uberlândia for allowing entry into their premises for the recruitment of research subjects; to the Dean of Graduate and Searching for financial aid who has paid for the hair analysis performed by the Biominerals Company and to the teacher Nivea for their support and for giving me access to the analytical chemistry laboratory spectroscopy applied to the achievement of my experiments.

\section{REFERENCES}

Alonso ML, Montaña FP, Miranda M, Castillo C, Hernández J, Benedito JL. 2004. Interactions between toxic ( $\mathrm{As}, \mathrm{Cd}, \mathrm{Hg}$ and $\mathrm{Pb}$ ) and nutritional essential $(\mathrm{Ca}, \mathrm{Co}$, $\mathrm{Cr}, \mathrm{Cu}, \mathrm{Fe}, \mathrm{Mn}, \mathrm{Mo}, \mathrm{Ni}, \mathrm{Se}, \mathrm{Zn}$ ) elements in the tissues of cattle from NW Spain. BioMetals, 17(1): 389-397.
Block GA, Klassen PS, Lazarus JM, Ofsthun N, Lowrie EG, Chertow GM. 2004. Mineral metabolism, mortality, and morbidith in maintenance hemodialysis. J. Am .Bsoc. Nephrol., 15(1): 2208-2218.

Brewer GJ. 2010. Risks of Copper and iron toxicity during aging in humans. Chem. Res. Toxicol., 23(1): 319-326.

Brewer GJ. 2012. Copper toxicity in Alzheimer's disease: Cognitive loss from ingestion of inorganic copper. J. Trace Elemt. Med. Biol., 26(1): 89-92.

Daniel KG, Harbach RH, Guida WC, Dou QP. 2004. Copper storage diseases: Menkes, Wilson's, and cancer. Front. Biosc., 9(1): 2652-2662.

Estela JM, Cerdá V. 2005. Flow analysis tecniques for phosphorus: an overview. Talanta., 66(1): 307.

Fraga CG. 2005. Relevance, essentiality and toxicity of trace elements in human health. Molec. Aspc. Med., 26(1): 235244.

Gaetke LM, Chow CK. 2003. Copper toxicity, oxidative stress, and antioxidant nutrients. Toxicology., 189(1): 147-163.

Kumar V, Abbas AK. 2006. Basic Pathological Diseases ( $7^{\text {th }}$ edn). Elsevier: Rio de Janeiro.

Madsen E, Gitlin JD. 2007. Copper and iron disorders of the brain. J. Neurosc., 30(1): 317-337.

Mancía SR, Neri IP, Ríos C, López LT, Espinosa LR, Montes S. 2010. The transition metals copper and iron in neurodegenerative diseases. Chem. Biol. Interact., 186(1): 184-199.

Marks DB. 2006. Basic Medical Biochemistry $\left(2^{\text {nd }}\right.$ edn). Academic Press: Philadelphia.

Miranda K, Amália GG, Dionísio ER, PereiraFilho ER. 2010. Copper determination in sugar cane sprits by fast sequential flame atomic absorption spectrometry using internal standardization. Microchem. J., 96(1): 99-101. 
Philippi ST. Editor Manole. 2003. Nutrition and Dietetics Technique ( $1^{\text {st }}$ edn). Academic Press: São Paulo.

Regina H, Déa FD. 2004. The insertion of the psychologist in preventive works on the abuse of alcohol and other drugs. Psyc. Scien. Profis., 24(1): 108-115.

Sena KCM, Pedrosa LFC. 2005. Zinc supplementation and its effects on growth, immune system, and diabetes. $J$. Nutrit., 18(2): 251-259.
Ross LJ, Wilson M, Banks M, Rezannah B, Daglish M. 2012. Prevalence of malnutrition and nutritional risk factors in patients undergoing alcohol and drug treatment. Nutrit., 28(1): 738-743.

Vieira OM, Neto MM. 2003. Disorders of fluid and electrolyte balance. J. Med., 36(1):325-337. 